\author{
Monica C Botelho ${ }^{1,2 *}$ and Helena Alves ${ }^{1}$ \\ ${ }^{1}$ INSA, National Institute of Health Dr. Ricardo \\ Jorge, Porto, Portugal \\ ${ }^{2}$ IPATIMUP/I3S, Institute of Pathology and \\ Molecular Immunology / Instituto de Investigação e \\ Inovação da Universidade do Porto, Portugal \\ Dates: Received: 12 January, 2016; Accepted: 21 \\ January, 2016; Published: 23 January, 2016 \\ *Corresponding author: Mónica C. Botelho, PhD, \\ INSA - National Institute of Health Dr. Ricardo \\ Jorge, Rua Alexandre Herculano, 321, 4000-055, \\ Porto, Portugal, Tel.: +351 223401 114; fax: +351 \\ 223401 109; E-mail: monicabotelho@hotmail.com; \\ monica.botelho@insa.min-saude.pt \\ www.peertechz.com
}

Keywords: Breast cancer; Endothelial progenitor cells; AC133; KDR, VEGF

\section{Editorial \\ Endothelial Progenitor Cells in Breast Cancer}

\section{Introduction}

Malignant transformation requires the generation of a fertile macro environment in which tumor cell proliferate, and under certain circumstances form a highly invasive and metastatic tissue [1,2].

The formation of new vessels within a tumor, angiogenesis, is dependent on proliferation and migration of endothelial cells [3]. Two possible sources of endothelial cells are (1) migration and co-option of pre-existing vascular walls endothelial cells or (2) recruitment of EPCs from the bone marrow [4].

Initial studies showed that EPCs could be identified by their expression pattern of specific cell-surface markers, which included Kinase Insert Domain Receptor (KDR) [4] and AC133 [5]. EPCs are tracked by the cell-surface molecule AC133, a five transmembranespanning $120 \mathrm{kD}$ glycoprotein [6,7]. It has been demonstrated previously that acute elevation of VEGF levels in vascular trauma patients is the primary factor inducing mobilization of EPCs [4] and it has been widely described that VEGF is up-regulated in most tumour types including those of the breast [8]. Gill and collaborators [4], have shown previously that late-outgrowth endothelial cells differentiating from the non-adherent population of plated Peripheral Blood Mononuclear Cells (PBMNCs) represent a population of BMderived anchorage-independent BM-derived EPCs characterized by high proliferative potential. These late-outgrowth colonies have been shown to be a characteristic of AC133+KDR+ cells [4]. There is a growing body of evidence showing that EPCs, AC133+KDR+ cells, might be implicated in the development of some tumors [9-11]. We analyzed the expression of EPC's markers in PBMNCs from breast cancer patients by RT-PCR. Our results suggest that a population of cells expressing AC133 and KDR are mobilized to the peripheral circulation in breast cancer patients. We found that $16.7 \%$ of breast cancer patients have circulating EPCs confirmed by the expression of AC133 and KDR markers [12]. These results are in agreement with several other authors who found that EPCs are recruited during breast cancer development [11-14]. Since VEGF plasma levels are elevated in vascular trauma patients in comparison to VEGF levels in plasma of healthy donors, we sought to evaluate the VEGF plasma levels in breast cancer patients. We and others found that VEGF plasma levels in these patients correlates with the presence of $\mathrm{AC} 133+\mathrm{KDR}+[11,12]$. Given that our observations show an increase of circulating progenitor cells in the peripheral blood of breast cancer patients, we sought to evaluate the expression of AC133 and KDR in breast tumors. For this purpose RT-PCR of frozen breast tumors and matching normal tissue was performed. We found that $88.9 \%$ of breast tumors express AC133 and KDR. In contrast, only $25.0 \%$ of the normal adjacent tissue expressed these markers [12]. To our knowledge there is no report in the literature at present addressing AC133 and KDR expression in breast tissue. The tumor specimens that did not express the EPC's markers were highly correlated with the size of the tumor $(115.0 \pm 4.1 ; \mathrm{p}=0.0004)$, the tumor weight (516.0 $\pm 34.1 ; \mathrm{p}=0.0088)$ and the age of the patient $(69 \pm 2.2 ; \mathrm{p}=0.0159)$ [12] These data suggest that breast tumors recruit EPCs in a very targeted and focal fashion and indicate that the tumor recruits EPCs during cancer progression and they are no longer needed when the tumor reaches a plateau of growth.

Taken together, these results show that breast cancer patients have elevated levels of VEGF and that these levels correlate with circulating AC133+KDR+ cells in these patients. Furthermore, the expression of these EPC's markers in a panel of breast tumors but not in the respective adjacent normal tissue highlights the importance of these cells as targets for breast cancer therapy. It is expected that these cells could be used as biomarkers of early diagnosis and treatment of breast cancer.

\section{References}

1. Marinho AF, Botelho M, Schmitt FC (2000) Evaluation of numerical abnormalities of chromosomes 1 and 17 in proliferative epithelial breast lesions using fluorescence in situ hybridization Pathology-Research and Practice 196: 227-233. 
2. Botelho MC, Teixeira JP, Oliveira PA (2014) Carcinogenesis. Encyclopaedia of Toxicology 2014; Third Edition, Elsevier, 713-729.

3. Folkman J (1995) Seminars in Medicine of the Beth Israel Hospital, Boston. Clinical applications of research on angiogenesis. N Engl J Med 333: 17571763.

4. Gill M, Dias S, Hattori K, Rivera ML, Hicklin D, et al. (2001) Vascular trauma induces rapid but transient mobilization of VEGFR2(+)AC133(+) endothelial precursor cells. Circ Res 88: 167-174.

5. Peichev M, Naiyer AJ, Pereira D, Zhu Z, Lane WJ, et al. (2000) Expression of VEGFR-2 and AC133 by circulating human CD34(+) cells identifies a population of functional endothelial precursors. Blood 95: 952-958.

6. Miraglia, Miraglia S, Godfrey W, Yin AH, Atkins K, et al. (1997) A novel fivetransmembrane hematopoietic stem cell antigen: isolation, characterization, and molecular cloning. Blood 90: 5013-5021.

7. Yin AH, Miraglia S, Zanjani ED, Almeida-Porada G, Ogawa M, et al. (1997) AC133, a novel marker for human hematopoietic stem and progenitor cells. Blood 90: 5002-5012.

8. Botelho MC, Soares R, Alves H (2015) Progesterone in Breast Cance Angiogenesis. SM J Reprod Health Infertil 1: pii: 1001.
9. Kim HK, Song KS, Kim HO, Chung JH, Lee KR, et al. (2003) Circulating numbers of endothelial progenitor cells in patients with gastric and breast cancer. Cancer Lett 198: 83-88.

10. Yu Y, Flint AF, Mulliken JB, Wu JK, Bischoff J (2004) Endothelial progenitor cells in infantile hemangioma. Blood 103: 1373-1375.

11. Tawada M, Hayashi S, Ikegame Y, Nakashima S, Yoshida K (2014) Possible involvement of tumor-producing VEGF-A in the recruitment of lymphatic endothelial progenitor cells from bone marrow. Oncol Rep 2359-2364.

12. Botelho M, Amendoeira I, Diamond J, Dias S, Schmitt F (2005) Breast tumors induce the recruitment of AC133+ KDR+ endothelial precursor cells mobilized by plasma vascular endothelial growth factor. Breast Cancer Research 7 : P5.06.

13. Richter-Ehrenstein C, Rentzsch J, Runkel S, Schneider A, Schönfelder G (2007) Endothelial progenitor cells in breast cancer patients. Breast Cancer Res Treat 106: 343-349.

14. Van't Hull EF, Bron S, Henry L, Ifticene-Treboux A, Turrini R, et al. (2014) Bone marrow-derived cells are implicated as a source of lymphatic endothelial progenitors in human breast cancer. Oncoimmunology 3: e29080.

Copyright: (c) 2016 Botelho MC, et al. This is an open-access article distributed under the terms of the Creative Commons Attribution License, which permits unrestricted use, distribution, and reproduction in any medium, provided the original author and source are credited. 